\title{
Simulasi Graphical User Interface Analisis Termodinamika Mesin Turboprop Menggunakan Perangkat Lunak Matlab R2020a
}

\author{
Bismil Rabeta ${ }^{1 *}$, Aswan Tajuddin ${ }^{2}$, Mohammad Abghi Firyal Ulhaq ${ }^{3}$, Agus \\ Sugiharto ${ }^{4}$ \\ 1,2,3Prodi Teknik Penerbangan, Fakultas Teknologi Kedirgantaraan, Universitas \\ Dirgantara Marsekal SuryadarmaKomplek Bandara Halim Perdanakusuma, Jakarta, \\ Indonesia \\ *Corresponding Author : bismilrabeta@gmail.com
}

\begin{abstract}
A turboprop engine is a hybrid engine that delivers thrust or jet thrust and also drives the propeller. This is basically similar to a turbojet except the turbine works throughthe main shaft which is connected to the reduction gear to rotate the propeller in front of the engine. This research was conducted to determine the development of engine performance in thermodynamic analysis so as to know the value of each parameter on a engine that has been developing for 20 to 50 years with different engine manufacturing. So that in this studya comparison of the thermodynamic analysis of the TPE-331, PT6A42 and H85-200 engineswas carried out. In the TPE331-10, PT6A-42, and H85-200 turboprop engines the value of fuel to air ratio and shaft work increases with increasing altitude while compressor work, fuel flow rate, shaft power, propeller thrust, jet thrust, total thrust, equivalent engine power and ESFC decrease with increasing altitude. Furthermore, the turbine's working value is relativelystable as the altitude increases. After that, the value of compressor work and turbine work onthe PT6A-42 engine was greater than that of the TPE331-10, and H85-200 engines. However, the value of the fuel to air ratio, fuel flow rate, shaft power, jet thrust, equivalent engine power and ESFC on the H85-200 engine was greater than the TPE331-10 and PT6A engines. Furthermore, at sea level, the value of the axle, propeller thrust, and total thrust on the H85-200 engine is greater than that of the TPE331-10 and PT6A-42 engines but at an altitude of 25,000 ft, the PT6A-4 engine has a greater value than that of the TPE331-10 and PT6A-42 engines. TPE331-10, and H85-200 engines.
\end{abstract}

Keywords: Turboprop, Thermodynamic, Propeller, and ESFC. 


\section{PENDAhUluAN}

L 410 NG adalah model terbaru dari pesawat L 410. Pengembangannya diluncurkan pada 2010 di bawah proyek MOSTA, produksi serial dimulai pada 2018. Model inovatif ini menawarkan flight envelope yang ditingkatkan, penggunaan teknologi canggih, dan avionic modern. Desain sayap yang baru dengan tangki bahan bakar terintegrasi memberikan peningkatan kapasitas bahan bakar, memungkinkan jangkauan dan daya tahan penerbangan yang jauh lebih lama. Perbaikan penting lainnya adalah peningkatan MTOW dan payload, yang menghasilkan kemampuan untuk membawa kargo 500 kg ekstra, dengan peningkatan volume yang disediakan oleh nose extension. Pesawat ini dilengkapi dengan mesin GE H85-200 yang lebih bertenaga yang disertifikasi pada tahun 2012 dan propeller AV 725. CASA C-212 merupakan pesawat yang ditenagai oleh dua engine turboprop untuk pesawat transportasi ringan dengan material logam dengan konfigurasi sayap high wing dan mempunyai jenis fixed tricycle landing gear. Pesawat ini dikenal dengan nama AVIOCAR yang digunakan untuk runways yang pendek baik pada saat take off dan landing (STOL). Pada eranya C-212merupakan jawaban CASA untuk angkatan udara dibidang transportasi militer ringan yang dapat beroperasi didaerah yang minim infrastruktur dan landasan pacu yang tidak beraspal. AVIOCAR iniditenagai oleh dua engine turboprop Garret TPE331-10 yang dirancang pada tahun 1959 dan disertifikasi pada tahun 1965, TPE331-10 adalah mesin turboprop pertama yang dikembangkan oleh perusahaan Garret Air Research dan kemudian pada tahun 1999 dibeli oleh perusahaan Honeywell. Pesawat produksi dalam negeri N-219 Nurtanio, saat ini masih berada dalam tahapan pengujian untuk mendapatkan Sertifikasi Tipe (Type Certificate) dari Direktorat Kelaikudaraan dan Pengoperasian Pesawat Udara (DKUPPU) Kementerian Perhubungan Republik Indonesia dengan mengantongi lebih dari 200 jam uji terbang (Flight Test). Mesin yang digunakan oleh pesawat $\mathrm{N}-219$ adalah mesin PT6A-42 berasal dari Pratt \&Whitney yang disertifikasi pada tahun 1983. Mesin ini merupakan mesin turboprop dimana mesin turboprop ini sangat efektif dan cocok digunakan di Indonesia. Mesin turboprop merupakan mesin yang memiliki konsumsi bahan bakar yang paling rendah dibandingkan dengan turbojet dan turbofan untuk ukuran mesin yang sama, selain itu mesin turboprop juga memiliki kemampuan short take-off landing yang baik $^{[1]}$ sehingga bisa digunakan untuk bandara perintis yang masih banyak terdapat di Indonesia. Untuk itu karena mesin penggerak turboprop ini dapat digunakan untuk bandara perintis yang ada di Indonesia maka sangat penting untuk mengetahui kinerja mesin dalam analisis termodinamika sehingga dapat mengetahui nilai parameter masingmasing pada mesin yang sudah mengalami pengembangan selama 20 hingga 50 tahun dengan manufaktur mesin yang berbeda. Sehingga pada penelitian ini dilakukan perbandingan analisis termodinamikamesin TPE-33110, mesin PT6A-42 dan mesin H85-200. Ouput yang ingin didapatkan pada tiaptiap mesin adalah gaya dorong propeller, kerja kompresor, fuel to air ratio, laju aliran bahan bakar, kerja turbin, kerja poros, daya poros, propeller thrust, jet thrust engine, total thrust, equivalent engine power danequivalent specific fuel consumption (ESFC). Setelah itu, 
dibandingkan nilai output ketiga mesin melalui grafik dan persentase.

\section{METODE PENELITIAN}

\subsection{Mesin Turboprop}

Mesin turboprop adalah mesin hybrid yang memberikan thrust atau jet thrust dan juga menggerakkan propeller. Ini pada dasarnya mirip dengan turbojet kecuali bahwa turbin bekerja melalui poros utama yang terhubung dengan reduction gearuntuk memutar propeller di depan mesin(Gambar 2.1).

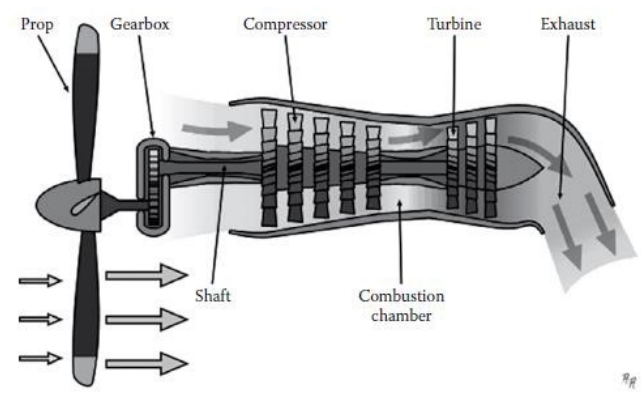

Gambar 2.1 Turboprop Engine [

Segera setelah turbojet pertama mengudara, mesin turboprop dikembangkan. Mesin turboprop memiliki konsep yang mirip dengan turbofan, meskipun memiliki bypass ratio yang lebih tinggi.

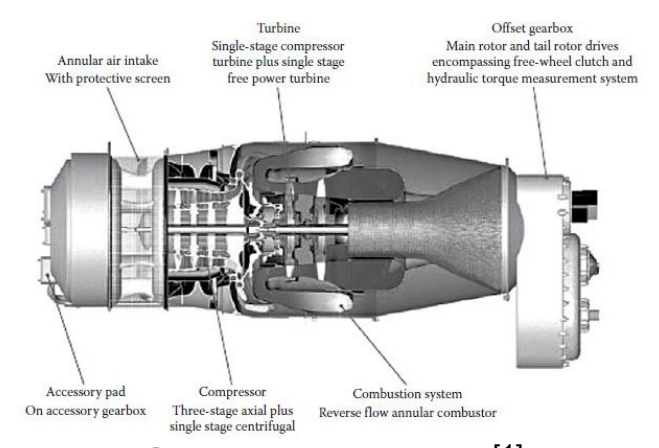

Gambar 2.2 PT6B ${ }^{[1]}$

Selain itu, alih-alih turbin yang menggerakkan ducted fan, turbin itu menggerakkan propeller eksternal sepenuhnya. Turboprop menggunakan core turbin gas untuk memutar propeller. Propeller digerakkan baik oleh turbin generator gas (Gambar 2.2), atau oleh turbin lain yang diklasifikasikan sebagai turbin bebas atau turbin listrik (Gambar 2.3). Dalam hal ini, turbin bebas atau free turbine tidak bergantung pada turbin compressor-drive dan bebas berputar dengan sendirinya dalam aliran gas buang atau exhaust mesin. Konfigurasi lain dari turboprop turbin bebas memiliki arah gas dan udara rear-to-front yang tidak konvensional. Konfigurasi ini memberikan fleksibilitas tinggi dalam desain nacelle instalasi yaitu ruang di belakang mesin yang tidak digunakan untuk ujung saluran pembuangan bisa digunakan untuk sumur roda atau tangki bahan bakar. Kompresor merupakan gabungan dari desain aliran aksial atau sentrifugal. Contoh dari mesin tersebut adalah PT6, diproduksi oleh Pratt \& Whitney dari Kanada.

Dalam kasus lain, heavy gearbox dipasang di antara turbin dan propeller dan memberikan pengurangan kecepatanhampir 1:15. Mesin turboprop menghasilkan dua gaya dorong, satu dengan propeller dan lainnya melalui exhaust. Thrust yang dikembangkan oleh propeller hampir $85 \%$ dari total thrust, sedangkan $15 \%$ sisanya diproduksi oleh jet core exhaust karena low-speed exhaust.

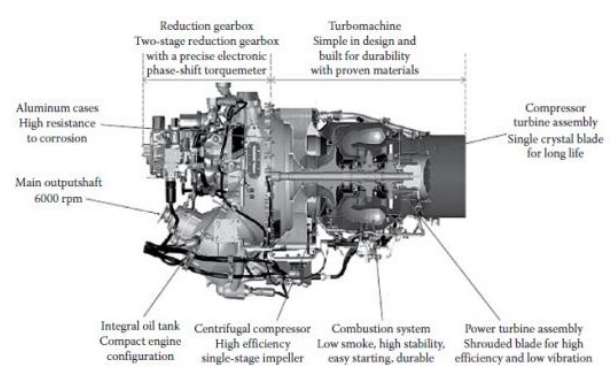

Gambar 2.3 PW200 [1] 
Seperti yang dinyatakan sebelumnya, propeller berputar dengan kecepatan yang sangat rendah dibandingkan dengan kecepatan penggeraknya turbin. Pengurangan kecepatan bisa jadi 1:15. Pengurangan kecepatan ini diperlukan untuk dua alasan:

1. Gaya sentrifugal yang besar muncul dari putaran propeller berdiameter besar (2-4 m, atau bahkan lebih). Bilahini dipasang ke hub propeller di konfigurasi kantilever fixended. Akibatnya, gaya sentrifugal tersebut menghasilkan tegangan tarik atau tensile stress yang besar di blade root. Stress limitations mengharuskanpropeller berdiameter besar berputar pada kecepatan yang jauh lebih lambat. Ini adalah fakta bahwa tidakada propeller yang dapat menahan tensile force (dan stress atautegangan) yang dihasilkan saat diputar dengan kecepatan yang sama dengan turbin.

2. Karena rotasi atau putaran propeller, kecepatan relatif di propeller tip akan mendekati kecepatan suara sebelum pesawat mendekati kecepatan suara.Efek kompresibilitas ini ketika mendekati kecepatan suara membatasi desain propeller. Pada kecepatan terbang subsonik tinggi $(\mathrm{M}>0,7)$, propeller tip dapat mendekat kecepatan supersonik. Jika ini terjadi, aliran dapat terpisah dan gelombang kejut dapat terbentuk. Akibatnya, kinerja mesin turboprop mengalami penurunan akibat efisiensi propelleryang buruk dan penurunan laju aliran udara ke dalam mesin.

\subsubsection{Keuntungan dan Kerugian Mesin Turboprop}

Keuntungan dari mesin Turboprop adalah:
1. Turboprop memiliki efisiensi bahan bakar yang tinggi, bahkan lebih besar dari mesin turbofan. Ini adalah karena sedikitnya aliran udara yang terbakar di dalam mesin. Mesin turboprop kemudian dapat menghasilkan thrust yang cukup besar pada konsumsi bahan bakar rendah.

2. Mesin turboprop dapat digunakan untuk Vertical Take-Off and Landing (VTOL). Pesawat Osprey V-22 adalah salah satu pesawat VTOL yang terkenal yang didukung oleh mesin turboprop.

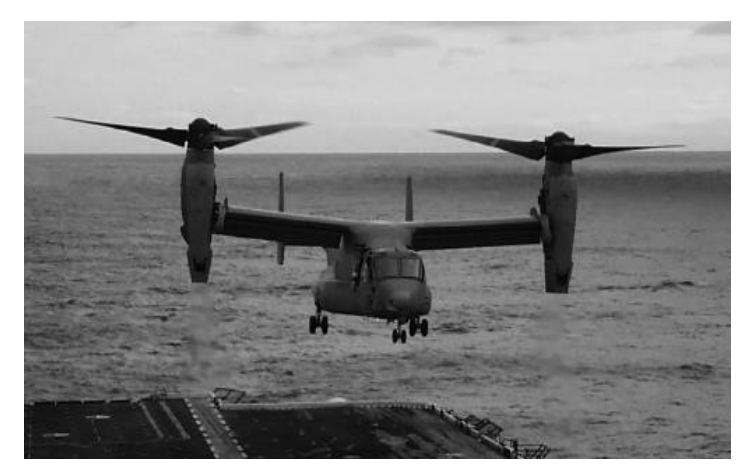

Gambar 2.4 V-22 Osprey [1]

3. Mesin turboprop memiliki take-off thrust yang tinggi sehingga memungkinkan pesawat dapat takeoffdi runway yang pendek.

4. Mesin turboprop memiliki efisiensi propulsi tertinggi untuk kecepatan penerbangan $400 \mathrm{mph}$ dibandingkan dengan mesin turbofan dan turbojet

Kerugian dari mesin Turboprop adalah:

1. Kebisingan dan getaran yang dihasilkan oleh propeller merupakan kelemahan yang signifikan.

2. Mesin turboprop terbatas pada penerbangan subsonik (kurang dari $400 \mathrm{mph}$ ) dan ketinggian yang rendah (di bawah $30.000 \mathrm{ft}$ ).

3. Propeller dan reduction gear box, pitch control mechanism dan turbin daya 
berkontribusi bobot tambahan, sehingga mesin turboprop mungkin 1,5 kali berat turbojet konvensional dengan ukuran generator gas yang sama.

4. Gearbox ukuran besar yang terhubung ke popeller terletak di hulu udara inlet mesin. Dengan demikian, bentuk intake berbeda dengan mesin turbojet dan mesin turbofan. Selain itu, gearbox (biasanya versi single atau double planetary) memiliki banyak bagian bergerak yang dapat rusak dan dapat mengotori aliran udara masuk kemesin.

\subsubsection{Klasifikasi Mesin Turboprop}

Ada banyak kesamaan antara mesin piston dan mesin turboprop, seperti yang akan dijelaskan.

\section{Berdasarkan konfigurasi mesin pesawat}

Mesin turboprop dapat berupa jenis tractor (kadang-kadang diidentifikasi sebagai puller) atau tipe pusher. Kata puller (tractor) berarti mesin turboprop dengan propeller yang mendahului intake dan kompresor. Thrust force (sebagian besar dihasilkan oleh propeller) dengan demikian merupakan pulling force. Sebagian besar pesawat digerakkan oleh konfigurasi puller (tractor). Jika propeller downstream dari inlet dan kompresor, maka turboprop jenis ini diidentifikasi sebagai pendorong, ditunjukkan pada Gambar 2.5.

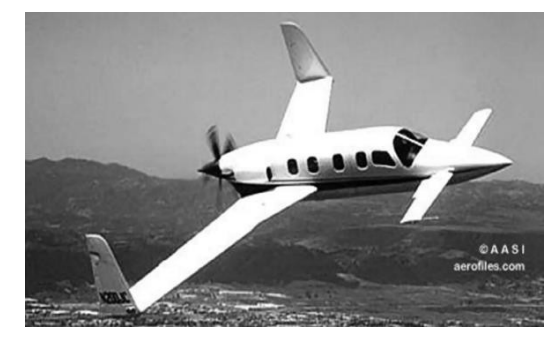

Gambar 2.5 Pusher Configuration of Jetcruzer 500, AASI Airplane ${ }^{[1]}$
Keuntungan dari mesin pusher turboprop:

a. Aliran udara yang berkualitas lebih tinggi (clean) terjadi di atas sayap.

b. Suara mesin di area kabin berkurang.

c. Bidang pandang depan pilot ditingkatkan.

\section{Kerugian dari mesin pusher}

\section{turboprop:}

a. Heavy Gearbox ada di belakang, yang menggeser pusat gravitasi ke belakang sehingga mengurangi stabilitas longitudinal.

b. Propeller lebih mungkin rusak oleh puing-puing yang beterbangan saat mendarat.

c. Masalah pendinginan mesin lebih parah.

Konfigurasi "pusher" tidak terlalu umum.

Contoh:

Jetcruzer 500 didukung oleh Pratt \& Whitney Canada (PT6A-66) dengan lima blades dengan kecepatan konstan.

2. Hartzell propeller Keuntungan dari mesin turboprop puller (tractor):

1. Heavy Gearbox ada di depan, yang membantu menggerakkan pusat gravitasi maju dan karena itu memungkinkan tail yang lebih kecil untuk stabilitas.

2. Propeller bekerja pada free stream yang tidak terganggu. Ada yang lebih efektif dari cooling air untuk mesin. Kerugian dari mesin turboprop puller (tractor):

a. Slipstream propeller mengganggu kualitas aliran udara di atas sayap.

b. Peningkatan kecepatan dan turbulensi aliran di atas fuselage akibat adanya propeller slipstream meningkatkan skinfriction lokal pada fuselage 


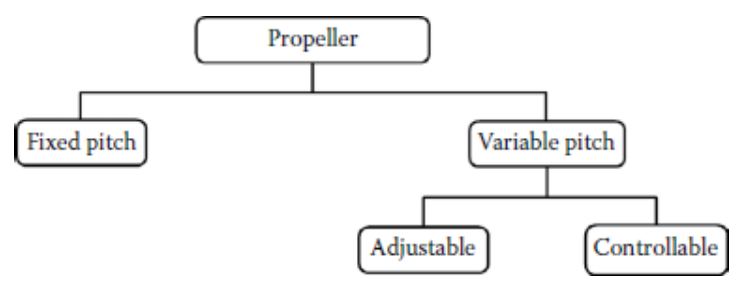

Gambar 2.6 Klasifikasi Propeller

Contoh:

Sebagian besar, jika tidak semua, pesawat yang ditenagai oleh turboprop memiliki konfigurasi puller. Pratt \& Whitney Canada (PW 120A), yang menggerakkan pesawat Dash 8, adalah sebuah model untuk tipe ini.

\section{Propeller-engine coupling}

Klasifikasi ini telah disebutkan dan bergantung pada cara propeller dan turbin digabungkan. Propeller mungkin digerakkan oleh gas generator atau dengan turbin terpisah (diidentifikasikan sebagai "free power" turbin).

\section{Number of spools}

Mesin turboprop dapat berupa single, double, atau triple spool. Propeller didorong oleh generator gas ditemukan baik dalam mesin turboprop single atau double spool. Sebaliknya, propeller yang digerakkan oleh free power turbine dapat menjadi bagian dari sebuah mesin turboprop double atau triple spool. Jumlah spool sama dengan jumlah turbin di mesin.

\section{Tipe Propeller}

Jenis propeller juga dapat diklasifikasikan, seperti yang ditunjukkan pada Gambar 2.5, sebagai fixed-pitch atau vatriable pitch. Propeller variable pitch selanjutnya dapat dibagi lagi menjadi ajustable atau controlable pitch.

\section{Tipe Intake}

Intake mungkin memiliki bentuk yang berbeda, seperti yang ditunjukkan pada Gambar 2.7. Bentuk-bentuk ini tergantung pada ukuran dan lokasi reduction gearbox yang digabungkan dengan propeller. Bentuk dari intake dapat berupa axial, axisymetric, axisymetric through plenum atau scoop, yang pada gilirannya, mungkin berbentuk elips, persegi panjang, annular, atau sebuah u-shape.

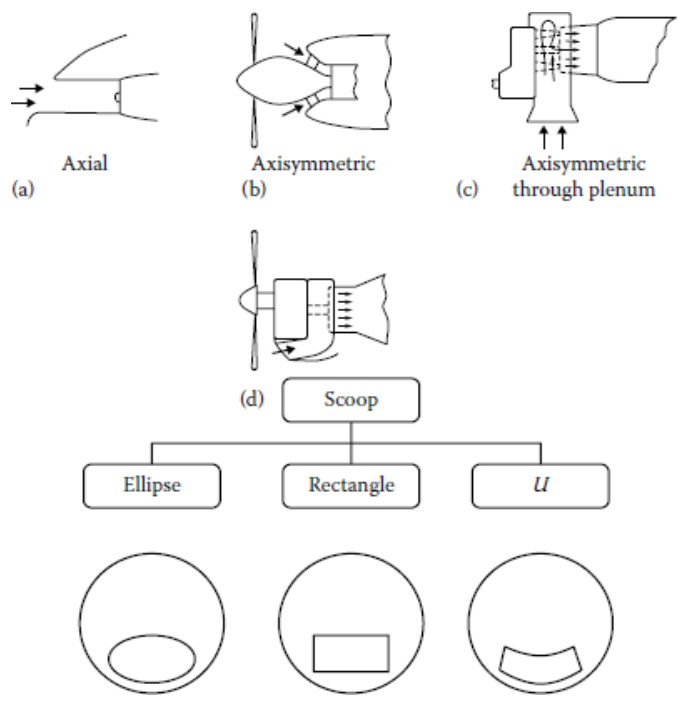

Gambar 2.7 Tipe-tipe Inlet ${ }^{[1]}$

\subsection{Analisis Termodinamika Mesin}

Dalam menganalisis kinerja mesin turboprop maka terlebih dahulu dilakukan studi literatur untuk mengetahui parameter- parameter yang dibutuhkan dalam perhitungan sesuai dengan referensi yang ada.

\subsubsection{Single-Spool dan Double-Spool Turboprop}

Jenis spool dari mesin TPE331-10 memiliki poros tunggal, sedangkan mesin PT6A-42 dan H85-200 memiliki poros ganda. Diagram temperatureentropy untuk single spool pada gambar 2.8 dan 2.9 . 


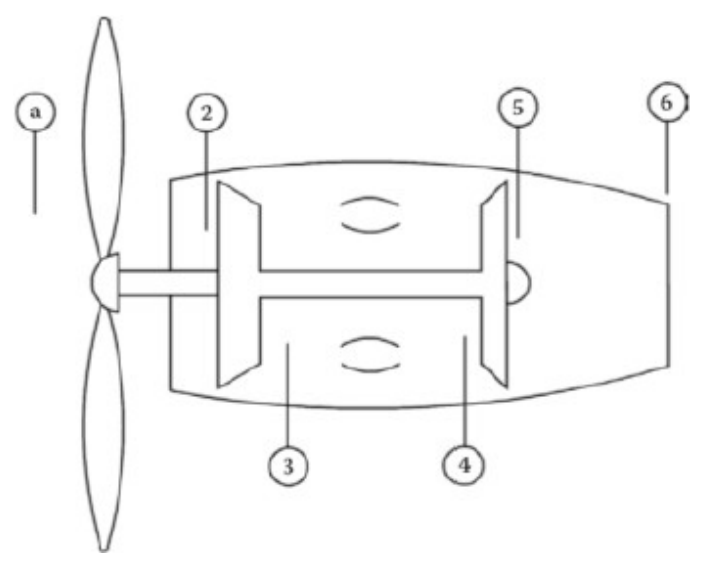

Gambar 2.8 Layout dari Single Spool Turboprop ${ }^{[1]}$

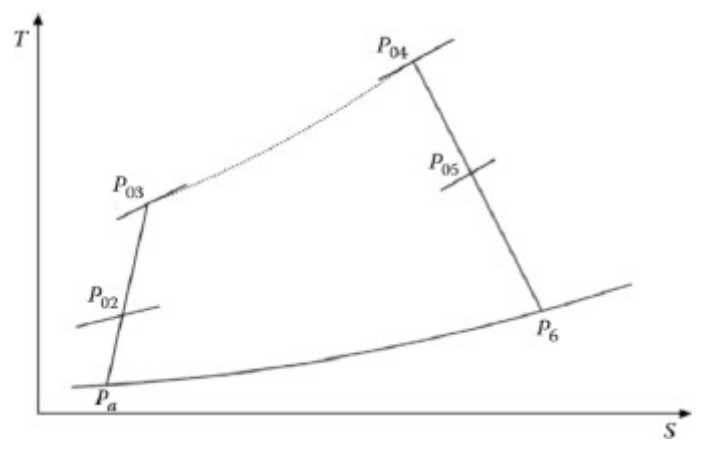

Gambar 2.9 Diagram TemperatureEntrophy Dari Single Spool Turboprop [1]

Kecepatan terbang dilambangkan sebagai

$$
\overline{U=} M_{a} \sqrt{ } \gamma R T_{a}
$$

Panas spesifik pada lokasi yang berbeda dapat dinyatakan sebagai berikut:

$$
\begin{aligned}
\gamma_{c}=\frac{C_{p c}}{\left(C_{p c}-R\right)}, & \gamma_{c c}=\frac{C_{p c c}}{\left(C_{p c c}-R\right)}, \\
\gamma_{t}=\frac{C_{p t}}{\left(C_{p t}-R\right)}, & \gamma_{n}=\frac{C_{n}}{\left(C_{n}-R\right)}
\end{aligned}
$$

\section{Intakes}

Intakes memiliki isentropic efficiency $\eta_{\text {d }}$, temperatur dan tekanan udara sekitar adalah $P_{a}$ dan $T_{a}$ dan kecepatan terbang sonic $M_{a}$. Temperatur dan tekanan pada saat keluar dari intake yaitu:

$$
\begin{aligned}
& P_{02}=P_{a}\left(1+\eta_{d} \frac{\gamma_{c}-1}{2} M_{a}^{2}\right)^{\frac{\gamma_{c}}{\gamma_{c}-1}} . \\
& T_{02}=T_{a}\left(1+\frac{\gamma_{c}-1}{2} M_{a}^{2}\right) \ldots \ldots \ldots \ldots . .
\end{aligned}
$$

\section{Compressor}

Untuk compressor pressure ratio yang diketahui $\pi_{c}$ merupakan isentropic efficiency $\eta_{c}$ dimana termperatur dan tekanan yang keluar dari compressor merupakan power specific compressor sebagai berikut :

$$
\begin{aligned}
P_{03} & =\left(P_{02}\right)\left(\pi_{c}\right) \ldots \ldots \ldots \ldots . . . \\
T_{03} & =T_{02}\left(1+\frac{\pi_{c} \frac{\gamma_{c}-1}{\gamma_{c}}-1}{\eta_{c}}\right) . \\
\Delta h_{c} & =C_{p c}\left(T_{03}-T_{02}\right) \ldots \ldots . . .
\end{aligned}
$$

\section{Combustion Chamber}

Proses pembakaran berlangsung didalamruang bakar dengan efisiensi $\eta_{b}$, Sementara produk dari pembakaran mengalami penurunan tekanan sebesar $-\Delta P$. Tekanan keluar dari ruang bakar dan perbandingan bahan bakar terhadap udara diberikan sebagai berikut :

$$
\begin{aligned}
& P_{04}=(1-\Delta P) P_{03} \\
& f=\frac{c p_{c c} T_{04}-c p_{c c} T_{03}}{\eta_{b} Q_{R}-C p_{c c} T_{04}} .
\end{aligned}
$$

Dari intake sampai dengan combustion chamber untuk jenis poros tunggal dan ganda masih memiliki nilai yang sama. Namun untuk poros yang ganda ada tambahan parameter setelah melewati combustion chamber yaitu generator gas, sebagai berikut:

Kesetimbangan energi antara kompresor dan turbin tekanan tinggi memberikan persamaan:

$\frac{\Delta h_{c}}{\eta_{m c}}=\eta_{m t} \Delta h_{t}$

Kerja spesifik yang dihasilkan dalam turbin sebagai gas generator adalah 


$$
\Delta h_{t}=C_{p t}\left(T_{04}-T_{05}\right)(1+f-b)
$$

Dari persamaan 2.8 dan 2.9 diketahui temperatur masuk turbin, sehingga tempertur yang keluar dari turbin adalah:

$$
T_{05}=T_{04}-\frac{c p_{c}\left(T_{03}-T_{02}\right)}{C p_{t} \eta_{m c} \eta_{m t}(1+f-b)} .
$$

Untuk efisiensi isentropik dari gas generator turbin, tekanan keluar $P_{05}$ sebagi berikut

$$
P_{05}=P_{04}\left(1-\frac{T_{04}-T_{05}}{\eta_{t} T_{04}}\right)^{\gamma_{t} / \gamma_{t}-1}
$$

\section{Turbine Untuk Single Spool Turboprop}

Ouput power dari turbine berkurang akibat adanya gesekan dari bantalan yang menyangga poros turbine. Kerugian ini dihitung sebagai turbine mechanical efficiency, $\eta_{m t}$. Selain itu, kerugianmekanikal yang dihasilkan pada bantalan yang menyangga kompresor dihitung sebagai kerugian yang disebut dengan compressor mechanical efficiency, $\eta_{m c}$. Perbedaaan antara turbine dan compressor power terletak reduction gearbox, dimana kerugian akibat gesekan dihasilkan dan dihitung sebagai gearbox mechanical efficiency $\eta_{g}$. Pada akhirnya output power yang dihasilkan dari propeller dinamakan propeller efficiency $\eta_{p r}$.

Telah ditunjukkan oleh Lancaster terdapat kecepatan exhaust optimum yang menghasilkan maksimum thrust untuk kecepatan terbang yang diberikan, turbine inlet temperature dan efisiensi yang diberikan.

Keterangan dari gambar 2.11 sebagai berikut:

$\Delta h=$ Penurunan entalpi terjadi pada turbin dan exhaust nozzle.

$\alpha \Delta h=\Delta h_{\text {ts }}$ dimana bagian dari $\Delta h$ yang tersedia dari isentropic turbine yang mempunyai perbandingan tekanan aktual.

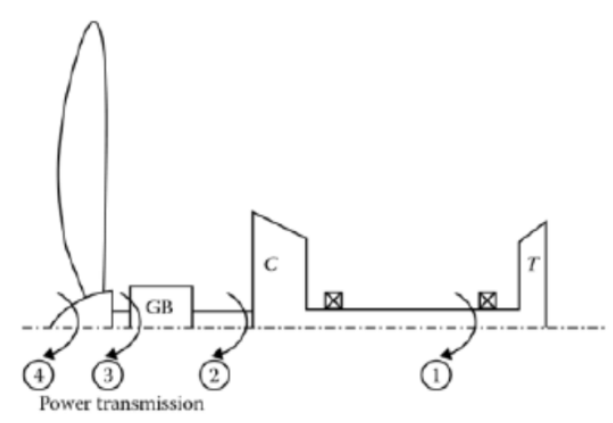

Pada Station 1, $\eta_{m t} W_{t}$

Pada Station 2, $\eta_{m t} W_{t}-\frac{W_{c}}{\eta_{m c}}$

Pada Station 3, $\eta_{g b}\left(\eta_{m t} W_{t}-\frac{W_{c}}{\eta_{m c}}\right)$

Pada Station 4, $\eta_{p r} \eta_{g}\left(\eta_{m t} W_{t}-\frac{W_{c}}{\eta_{m c}}\right)$

Gambar 2.10. Power Transmission Melalui Single Spool Turboprop Engine

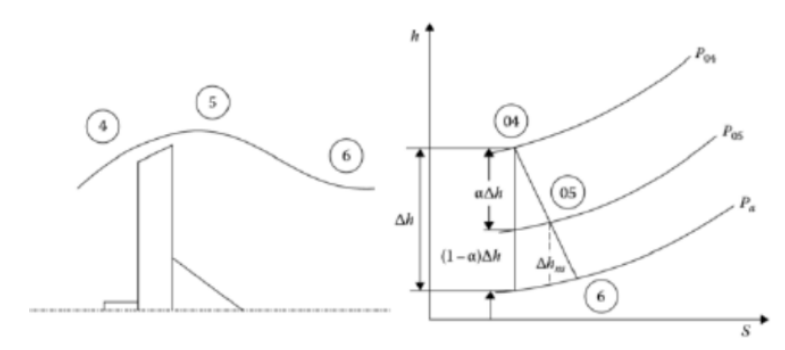

Gambar 2.11 Ekspansi Di Turbin Dan Nozel Dari Single Spool Turboprop Engine

$$
\Delta h_{n s}=(1-\alpha) \Delta h
$$

dimana merupakan bagian dari $\Delta h$ yangada pada isentropic nozzle.

$\eta_{\mathrm{t}}=$ Isentropic Efficiency Turbine

$\eta_{\mathrm{n}}=$ Isentropic Efficiency Of The ExhaustNozzle sehingga persamaan $\Delta h$ menjadi:

$$
\Delta h=C_{p t} T_{04}\left[1-\left(\frac{P_{a}}{P_{04}}\right)^{\gamma_{h}-1 / \gamma_{h}}\right] \ldots
$$

perbandingan antara panas spesifik dengan turbine dan nozzle adalah konstan sehingga:

$$
\gamma_{t}=\gamma_{n}=\gamma_{h}
$$


Jurnal Teknologi Kedirgantaraan, Vol, VI No. 2, Agustus 2021, P-ISSN 2528-2778, E-ISSN 2684-9704 https://doi.org/10.35894/jtk.v6i2

Kecepatan gas di exhaust $U_{e}$ dinyatakan dalam hubungan sebagai berikut

$\frac{U_{e}^{2}}{2}=\eta_{n}(1-\alpha) \Delta h$

$U_{e}=\sqrt{2(1-\alpha) \Delta h \eta_{n}}$

thrust yang dihasilkan oleh propeller $T_{p r}$ adalah

$T_{p r}=\frac{\dot{m}_{a} \eta_{p r} \eta_{g} W_{\text {shaft }}}{U}$

Shaft Power

$W_{\text {shaft }}=\eta_{m t}(1+f-b) \Delta h_{t}-\frac{\Delta h_{c}}{\eta_{m c}} \ldots .$.

dimana turbine specific power adalah

$\Delta h_{t}=\eta_{t} \alpha \Delta h$

ma adalah laju udara terinduksi per detik dan perbandingan bahan bakar dengan udara serta perbandingan bleed didefinisikan sebagai: $U_{e}=U \frac{\eta_{n}}{\eta_{p r} \eta_{g} \eta_{m t} \eta_{t}}$

$f=\frac{\dot{m}_{f}}{\dot{m}_{a}} \operatorname{dan} b=\frac{\dot{m}_{b}}{\dot{m}_{a}}$

$T_{p r}=\frac{\dot{m}_{a} \eta_{p r} \eta_{g}}{U}\left[(1+f-b) \Delta h_{t}-\frac{\Delta h_{c}}{\eta_{m c}}\right] .$.

Thrust force yang didapatkan dari gas exhaust yang meninggalkan Nozzle disingkat dengan $T_{n}$, jika laju aliran massa bahan bakar dan aliran bertekanan dari kompresor diperhitungkan sehingga menghasilkan hubungan:

$T_{n}=\dot{m}_{a}\left[(1+f-b) U_{e}-U\right]$.

dengan demikian total thrust

$T_{n}=\dot{m}_{a}\left[(1+f-b) U_{e}-U\right]$.

dengan demikian total thrust

$T=T_{p r}+T_{n}$

$\frac{T}{\dot{m}}=\frac{\eta_{p r} \eta_{g}}{U}\left[(1+f-b) \eta_{m t} \eta_{t} \alpha \Delta h-\frac{\Delta h_{c}}{\eta_{m c}}\right]$

$$
+[(1+f-
$$

b) $\left.\sqrt{2(1-\alpha) \Delta h \eta_{n}}-U\right]$. dengan mensubtitusi nilai dari $\alpha$ pada persamaan (2.21) diatas untuk menghasilkan maksimum harga thrust force. Maka persamaan yang digunakan untuk kecepatan exhaust gas adalah $U_{e}=U \frac{\eta_{n}}{\eta_{p r} \eta_{g} \eta_{m t} \eta_{t}}$

\section{Free Power Turbine Untuk Double Spool Turboprop Engine}

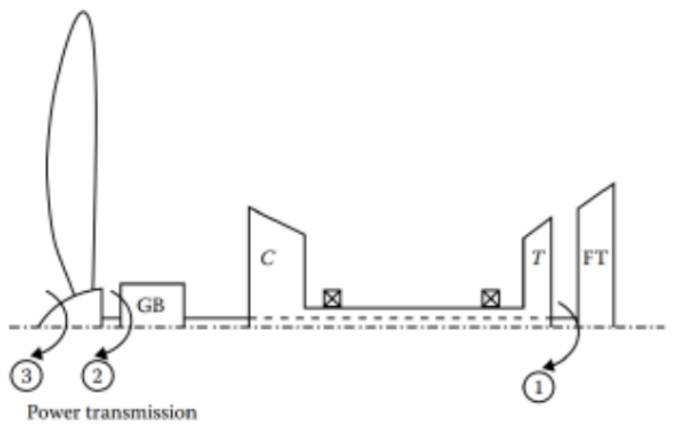

Pada Station 1, $\eta_{m f t} W_{f t}$

Pada Station 2, $\eta_{g b} \eta_{m f t} W_{f t}$

Pada Station 3, $\eta_{p r} \eta_{g b} \eta_{m f t} W_{f t}$

Gambar 2.12 Daya Tranmisi Untuk Mesin Poros Ganda

Pada gambar 2.12 ditunjukkan aliran daya dari free turbine ke propeller. Kerja yang dihasilkan oleh free power turbine per satuan massa yang diberikan kedalamengine adalah:

$$
\Delta h_{f t}=C_{p f t}(1+f-b)\left(T_{05}-T_{06}\right) \ldots . .
$$

Dari persamaan diatas maka temperatur $T_{06}$ tidak diketahui dan tidak dapat dihitung. Oleh karena itu, prosedur yang sama dengan single turboprop akan digunakan. Untuk proses ekspansi berlebih pada free power turbine dan nozzle dimana $\Delta h=$ entalpi turun secara isentropic didalam turbin dan exhaust nozzle, jika diasumsikan ekpansi keseluruhan terjadi menuju ke ke tekanan disekitar mesin maka diasumsikan tekanan didalam nozzle $P_{7}=P_{\mathrm{a}}$ yang dihitung sebagai berikut:

$\Delta h=C_{p t} T_{05}\left[1-\left(\frac{P_{7}}{P_{05}}\right)^{\gamma_{t}-1 / \gamma_{t}}\right] \ldots \ldots \ldots \ldots$ 

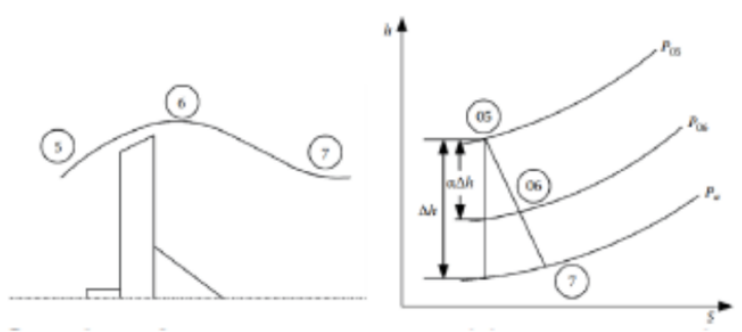

Gambar 2.13 Ekspansi Di Turbin Dan NozelUntuk Double Spool Turboprop Engine

$\alpha \Delta h=\Delta h_{f s}$ dimana bagian dari $\Delta h$ akan ada dari bentuk free power turbine yang mempunyai perbandingan tekanan aktual:

$$
\Delta h_{f t}=\eta_{f t} \Delta h_{f t}
$$

$\eta_{\mathrm{ft}}=$ efisiensi isentropic dari free power turbine.

Mengikuti prosedur yang sama seperti sebelumnya maka pada poros ganda untuk memnentukan optimum $\alpha$, propeller thrust dan exhaust thrust ditentukan lewat hubungan:

$$
\begin{aligned}
& T_{p r}=\frac{\dot{m}_{a} \eta_{p r} \eta_{g}}{U}\left[(1+f-b) \eta_{m f t} \eta_{f t} \alpha \Delta h\right] \\
& T_{n}=\dot{m}_{a}\left[(1+f-b) U_{e}-U\right] \ldots \ldots \ldots \ldots \ldots \ldots \ldots \ldots \ldots \ldots \ldots \ldots \ldots \ldots \ldots \ldots \ldots \ldots \ldots \\
& \ldots
\end{aligned}
$$

Maka gaya dorong total (Total Thrust):

$$
\begin{aligned}
& \frac{T}{\dot{m}}=\frac{\eta_{p r} \eta_{g}}{U}\left[(1+f-b) \eta_{m f t} \eta_{f t} \alpha \Delta h\right] \\
& +[(1+f- \\
& \text { b) } \left.\sqrt{2(1-\alpha) \Delta h \eta_{n}}-U\right]
\end{aligned}
$$

Dimana $\eta_{m f t}$ merupakan efisiensi mekanikal untuk free power turbine. Dengan memaksimalkan thrust $\mathrm{T}$ untuk efisiensi komponen, kecepatan terbang dan $\Delta h$ menghasilkan harga optimum dari $\alpha_{\text {opt: }}$ :

$$
\alpha_{o p t}=1-\frac{U^{2}}{2 \Delta h}\left(\frac{\eta_{n}}{\eta_{p r}^{2} \eta_{g}^{2} \eta_{m t}^{2} \eta_{t}^{2}}\right)
$$

Kecepatan aliran gas dihasilkan dari:

$$
U_{e}=U \frac{\eta_{n}}{\eta_{p r} \eta_{g} \eta_{m f t} \eta_{f t}} \text {. }
$$

\subsection{Equivalent Engine Power}

\subsubsection{Kondisi Statis}

Selama pengujian atau kondisi takeoff, total equivalent horsepower (TEHP) sama dengan shaft horsepower (SHP) ditambah SHP equivalent dengan daya dorong jet. Untuk estimasi, diasumsikan bahwa pada kondisi statis permukaan laut, satu SHP adalah setara dengan sekitar 2,6 Ib jet dorong. Jadi

$(\text { TEHP })_{\text {take-off }}=S H P+\frac{\text { et Thrust }(l b)}{2.6}$

Jika beralih ke Satuan Internasional (SI), maka

$$
\begin{aligned}
& {[T E P(k W)]_{\text {take-off }}} \\
& \text { Jet Thrust(Newton) } \\
& 8.5
\end{aligned}
$$

Nilai Thrust pada Ground Testing atau selama Take-off adalah

$$
T=\dot{m}(1+f-b) U_{e} \text {. }
$$

\subsubsection{Operasi Terbang}

Untuk sebuah mesin turboprop selama terbang, equivalent shaft horsepower (ESHP) sama dengan SHP ditambah jet thrust power.

$$
E S H P=S H P+\frac{T x U}{\text { Constant } x \eta_{p r}} .
$$

Dimana Thrust adalah

$$
T=m\left[(1+f \dot{-} b) U_{e}-U\right] .
$$

ESHP jika beralih ke Satuan Internasional(SI), maka

Equivalent Power $(k W)=P_{\text {Propeller }}+P_{\text {Jet }}$

\subsection{Fuel Consumption}

Untuk mesin turbojet dan turbofan, fuel consumption diidentifikasikan dengan thrust specific fuel consumption (TSFC), ditentukan dengan $T S F C=\dot{m} . f / T$ 
Dalam satuan kg fuel/N.h. Sedangkan, untuk mesin turboprop, fuel consumption diidentifkasikan dengan equivalent specific fuel consumption (ESFC), ditentukan sebagai

$E S F C=\frac{\dot{m} f}{E S H P}$

Dinyatakan dalam satuan $\mathrm{lb}$ fuel/hp.h ataukg fuel/kW.h.

Nilai tipikal untuk ESFC adalah 0.45 $0.60 \mathrm{lbfuel} / \mathrm{hp} . \mathrm{h}$, atau $0.27-0.36 \mathrm{~kg}$ fuel/kW.h.

\subsection{Gambaran Umum Aplikasi Matlab R2020a}

Matlab adalah bahasa pemrograman level tinggi yang dikhususkan untuk komputasi teknis. Bahasa ini mengintegrasikan kemampuan komputasi, visualisasi dan pemrograman dalam sebuah lingkungan yang tunggal dan mudah digunakan. Matlab memberikan sistem interaktif yang menggunakan konsep array/matrix sebagai standar variabel elemennya tanpa membutuhkan pen-deklarasi-an array seperti pada bahasa lainnya.

Matlab dikembangkan oleh MathWorks, yang pada awalnya dibuat untuk memberikan kemudahan mengakses data matrik pada proyek LINPACK dan EISPACK. Selanjutnya menjadi sebuah aplikasi untuk komputasi matrik. Dari sejak awal dipergunakan, matlab memperoleh masukan ribuan pemakai. Dalam lingkungan pendidikan ilmiah menjadi alat pemrograman standar bidang matematika, rekayasa dan keilmuan terkait. Dan dalam lingkungan industri menjadi pilihan paling produktif untuk riset, pengembangan dan analisa.

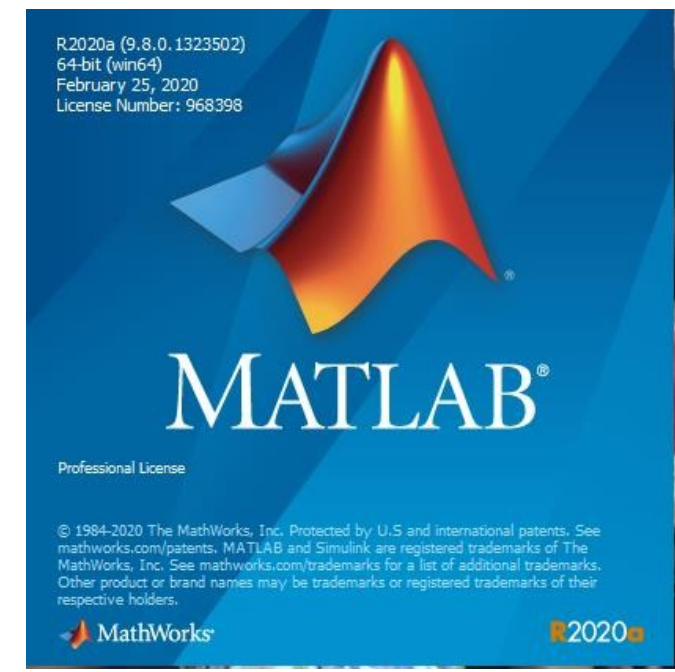

\section{Gambar 2.14 Matlab R2020a}

Matlab menyediakan beberapa pilihan untuk dipelajari, mempelajari metoda visualisasi saja, pemrograman saja atau kedua-duanya. Kemudahan yang ditawarkan sama sekali bukan tandingan bahasa pemrograman yang lain, karena bahasa pemrograman yang lain memang tidak menawarkan kemudahan serupa.

Matlab memang dihadirkan bagi orang-orang yang tidak ingin disibukkandengan rumitnya sintak dan alur logika pemrograman, sementara pada saat yang sama membutuhkan hasil komputasi dan visualisasi yang maksimal untuk mendukung pekerjaannya. Selain itu Matlab juga memberikan keuntungan bagi programer-developer program yaitu untukmenjadi program pembanding yang sangat handal, hal tersebut dapat dilakukan karena kekayaannya akan fungsi matematika, fisika, statistik dan visualisasi. 


\section{HASIL DAN PEMBAHASAN}

\subsection{Analisis Turboprop Engine}

\section{Analisis Turboprop Engine} Menggunakan Software

Analisis perhitungan pada mesin turboprop TPE331-10, PT6A-42 dan H85-200 dilakukan pada kecepatan jelajah maksimum (cruising speed) dengan beberapa variasi ketinggian, yaitu pada ketinggian $0 \mathrm{ft}, 5000 \mathrm{ft}, 10000$ $\mathrm{ft}, 15000 \mathrm{ft}, 20000 \mathrm{ft}$, dan $25000 \mathrm{ft}$.

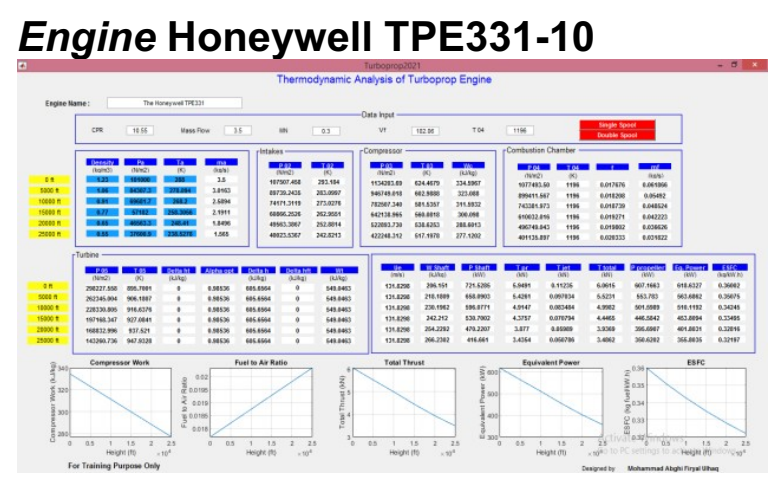

Gambar 4.1 Hasil GUI Analisis

Termodinamika Turboprop TPE331-10

\section{Engine Pratt \& Whitney PT6A-42}

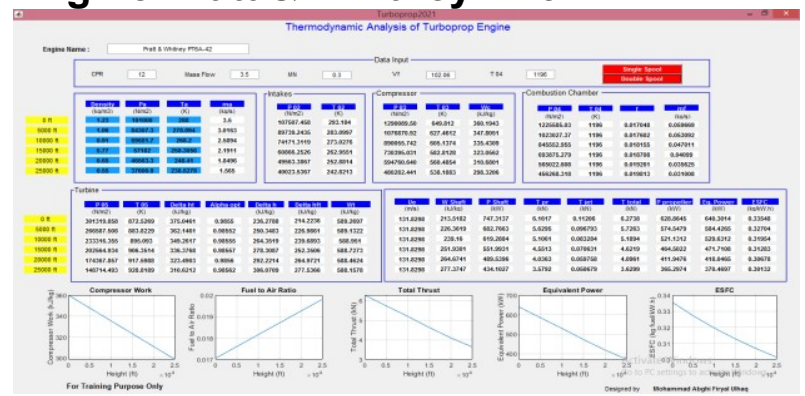

Gambar 4.2 Hasil GUI Analisis Termodinamika Turboprop PT6A-42

\section{Engine General Electric H85-200}

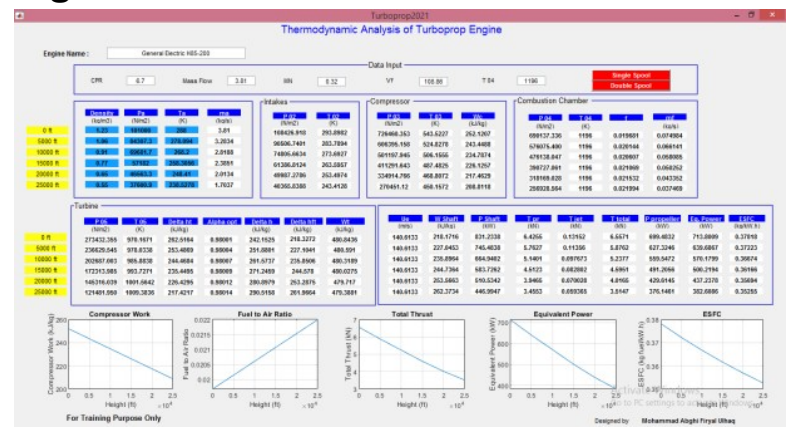

Gambar 4.3 Hasil GUI Analisis

Termodinamika Turboprop H85-200

\section{Analisis Turboprop Engine Menggunakan Perhitungan Manual}

Analisis perhitungan manual pada mesin turboprop TPE331-10 dilakukan pada kecepatan jelajah maksimum pesawat CASA 212 dengan ketinggian sea level. Diketahui nilai parameter pada pesawat CASA 212 dengan engine TPE331-10 pada ketinggian sea level adalah sebagai berikut:

\begin{tabular}{|c|c|}
\hline Mach number $\left(\mathrm{M}_{\mathrm{a}}\right.$ & $=0.3 \mathrm{M}$ \\
\hline Air flow rate $\left(\mathrm{M}_{\mathrm{a}}\right)$ & $=3.5 \mathrm{~kg} / \mathrm{s}$ \\
\hline \multicolumn{2}{|c|}{ Composer pressur ratio $\left(\pi_{c}\right)=10.55$} \\
\hline Temperature & $=288 \mathrm{~K}$ \\
\hline Pressure & $=101000 \mathrm{~N} / \mathrm{m}^{3}$ \\
\hline Density $(\rho)$ & $=1.23 \mathrm{~kg} / \mathrm{m}^{3}$ \\
\hline Flight speed (U) & $=102.06 \mathrm{~m} / \mathrm{s}$ \\
\hline
\end{tabular}

1. $\mathrm{P}_{02}=$ Pressure pada stage 2 (Intake)

$$
\begin{aligned}
P_{02} & =P_{a}\left(1+\eta_{d} \frac{\gamma_{c}-1}{2} M_{a}^{2}\right)^{\gamma c / \gamma c-1} \\
& =101000\left(1+1 . \frac{1.4-1}{2} 0.3^{2}\right)^{1.4 / 1.4-1} \\
& =107507.5 \mathrm{~N} / \mathrm{m}^{2} \\
\text { 2. } \mathrm{T}_{02} & =\text { Temperature diffuser } \\
T_{02} & =T_{a}\left(1+\frac{\gamma_{c}-1}{2} M_{a}^{2}\right) \\
& =288\left(1+\frac{1.4-1}{2}\right) 0.3^{2} \\
& =293.184 \mathrm{~K}
\end{aligned}
$$


3. $\mathrm{P}_{03}=$ Pressure pada stage 3 (Compressor)

$$
\begin{aligned}
P_{03} & =\left(P_{02}\right)\left(\pi_{c}\right) \\
& =(107507.5)(10.55) \\
& =1134203.69 \mathrm{~N} / \mathrm{m}^{2}
\end{aligned}
$$

4. $T_{03}=$ Temperature compressor

$$
\begin{aligned}
T_{03} & =T_{02}\left(1+\frac{\pi_{c} \frac{\gamma_{c}-1}{\gamma c}-1}{\eta_{c}}\right) \\
& =293.184\left(1+\frac{10.55^{\frac{1.4-1}{1.4}}-1}{0.85}\right) \\
& =624.47 \mathrm{~K}
\end{aligned}
$$

5. $\Delta \mathrm{h}_{\mathrm{c}}=$ Perubahan entalpi compressor

$$
\begin{aligned}
\Delta h_{c} & =C_{p c}\left(T_{03}-T_{02}\right) \\
& =1.01(624.47-293.184) \\
& =334.6 \mathrm{~kJ} / \mathrm{kg}
\end{aligned}
$$

6. $\mathrm{P}_{04}=$ Pressure pada stage 4 (Combustion Chamber)

$$
\begin{aligned}
P_{04} & =(1-\Delta P) P_{03} \\
& =(1-0.05) 1134203.69 \\
& =1077494 \mathrm{~N} / \mathrm{m}^{2}
\end{aligned}
$$

7. Fuel to air ratio

$$
\begin{aligned}
f & =\frac{C p_{c c} T_{04}-C p_{c c} T_{03}}{\eta_{b} Q_{R}-C p_{c c} T_{04}} \\
& =\frac{1.13 \times 1196-1.13 \times 624.47}{0.98 \times 43000-1.13 \times 1196} \\
& =0.0177
\end{aligned}
$$

8. Fuel flow rate

$$
\begin{aligned}
m_{f} & =m_{a} \times f \\
& =3.5 \times 0.0177 \\
& =0.0619 \mathrm{~kg} / \mathrm{s}
\end{aligned}
$$

9. $\Delta \mathrm{h}=$ Perubahan entalpi

$$
\begin{aligned}
& \Delta h=C_{p t} T_{04}\left[1-\left(\frac{P_{a}}{P_{04}}\right)^{\gamma_{h}-1 / \gamma_{h}}\right] \\
& = \\
& 1.14 x 1196\left[1-\left(\frac{101000}{1077494}\right)^{1.33-1 / 1.33}\right] \\
& =605.66 \mathrm{~kJ} / \mathrm{kg}
\end{aligned}
$$

10. $\alpha=$ Alpha optimum

$$
\begin{aligned}
& \alpha_{\text {opt }}=1-\frac{U^{2}}{2 \Delta h}\left(\frac{\eta_{n}}{\eta_{p r}^{2} \eta_{g}^{2} \eta_{m t}^{2} \eta_{t}^{2}}\right) \\
& = \\
& 1-\frac{102.06^{2}}{2 \times 605.66}\left(\frac{0.98}{(0.85 \times 0.99 \times 0.98 \times 0.92)^{2}}\right) \\
& \quad=0.985
\end{aligned}
$$

11. $\mathrm{U}_{\mathrm{e}}=$ Exhaust speed

$$
\begin{aligned}
U_{e} & =U \frac{\eta_{n}}{\eta_{p r} \eta_{g} \eta_{m t} \eta_{t}} \\
& =102.06 \times \frac{0.98}{0.85 \times 0.99 \times 0.98 \times 0.92} \\
& =131.83 \mathrm{~m} / \mathrm{s}
\end{aligned}
$$

12. $\Delta \mathrm{h}_{\mathrm{t}}=$ Perubahan entalpi turbine

$$
\begin{aligned}
\Delta h_{t} & =\eta_{t} \alpha \Delta h \\
& =0.82 \times 0.985 \times 605.66 \\
& =549.05 \mathrm{~kJ} / \mathrm{kg}
\end{aligned}
$$

13. $\mathrm{W}_{\text {shaft }}=$ Kerja poros

$$
\begin{aligned}
W_{\text {shaft }} & =\eta_{m t}(1+f) \Delta h_{t}-\frac{\Delta h_{c}}{\eta_{m c}} \\
& =0.98(1+0.0177) 549.05- \\
\frac{334.6}{0.98} & =206.15 \mathrm{~kJ} / \mathrm{kg}
\end{aligned}
$$

14. $\mathrm{P}_{\mathrm{s}}=$ Daya poros

$$
\begin{aligned}
P_{s} & =m_{a} \times W_{s} \\
& =3.5 \times 206.15 \\
& =206.15 \mathrm{~kW}
\end{aligned}
$$

15. $\mathrm{T}_{\mathrm{pr}}=$ Propeller thrust

$$
\begin{aligned}
T_{p r} & =\frac{\dot{m}_{a} \eta_{p r} \eta_{g} W_{\text {shaft }}}{U} \\
& =\frac{3.5 \times 0.85 \times 0.99 \times 206.15}{102.06} \\
& =5.95 \mathrm{kN}
\end{aligned}
$$

16. $\mathrm{T}_{\mathrm{j}}=$ Jet thrust

$$
\begin{aligned}
T_{j} & =\dot{m}_{a}\left[(1+f) U_{e}-U\right] \\
& =3.5[(1+0.0177) 131.83-
\end{aligned}
$$

102.06]

$$
=112.35 \mathrm{~N}=0.11 \mathrm{kN}
$$

17. $\mathrm{T}=$ Total thrust

$$
\begin{aligned}
T & =T_{p r}+T_{j} \\
& =5.95+0.11 \\
& =6.06 \mathrm{kN}
\end{aligned}
$$


18. $\mathrm{P}_{\mathrm{pr}}=$ Daya Propeller

$$
\begin{aligned}
P_{p r} & =U \times T_{p r} \\
& =102.06 \times 5.95 \\
& =607.17 \mathrm{~kW}
\end{aligned}
$$

19. $\mathrm{Eq}_{\mathrm{p}}=$ Equivaent engine power

$$
\begin{aligned}
E q_{p} & =P_{p r}+\left(U x T_{j}\right) \\
& =607.17+(102.06 \times 0.11) \\
& =618.63 \mathrm{~kW}
\end{aligned}
$$

20. ESFC

$$
\begin{aligned}
E S F C & =\frac{m_{f}}{E q_{p}} \times 3600 \\
& =\frac{0.0619}{618.63} \times 3600 \\
& =0.36 \frac{\mathrm{kg}}{\mathrm{kW}} . \mathrm{h}
\end{aligned}
$$

\subsection{Perbandingan Analisis Termodinamika Turboprop Engine}

Setelah mengetahui hasil analisis perhitungan dengan memakai GUI Matlab, maka akan dilakukan perbandingan. Perbandingan termodinamika turboprop engine akan dilakukan pada engine TPE331-10, PT6A-42, dan H85-200.

\subsubsection{Kerja Kompresor}

Pada gambar 4.4 ditunjukkan grafik kerja kompresor terhadap variasi ketinggian untuk setiap engine. Pada grafik tersebut dapat dilihat bahwa seiring dengan kenaikan ketinggian maka kerja kompresor mengalami penurunan karena suhu mengalami penurunan seiring kenaikan ketinggian. Pada grafik tersebut juga ditunjukkan bahwa kerja kompresor untuk mesin PT6A-42 memiliki nilai yang lebih tinggi $7.1 \%$ dibandingkan dengan kerja kompresor mesin TPE-331 dan 30\% dibandingkan dengan kerja kompresor mesin H85-200 karena nilai compressor pressure ratio mesin PT6A-42 lebih tinggi dibandingkan dengan TPE-331 dan H85200.
Tabel 4.1 Perbandingan Kerja Kompresor antara Engine TPE331-10, PT6A-42 dan H85-200 terhadap Variasi Ketinggian

\begin{tabular}{|c|c|c|c|}
\hline \multirow{2}{*}{$\begin{array}{c}\text { Ketinggian } \\
\text { (ft) }\end{array}$} & \multicolumn{3}{|c|}{ Kerja Kompresor (kJ/kg) } \\
\cline { 2 - 4 } & TPE331-10 & PT6A-42 & H85-200 \\
\hline $\mathbf{0}$ & 334.60 & 360.19 & 252.12 \\
\hline $\mathbf{5 0 0 0}$ & 323.09 & 347.81 & 243.45 \\
\hline $\mathbf{1 0 0 0 0}$ & 311.59 & 335.43 & 234.79 \\
\hline $\mathbf{1 5 0 0 0}$ & 300.10 & 323.06 & 226.13 \\
\hline $\mathbf{2 0 0 0 0}$ & 288.60 & 310.68 & 217.46 \\
\hline $\mathbf{2 5 0 0 0}$ & 277.12 & 298.32 & 208.81 \\
\hline
\end{tabular}

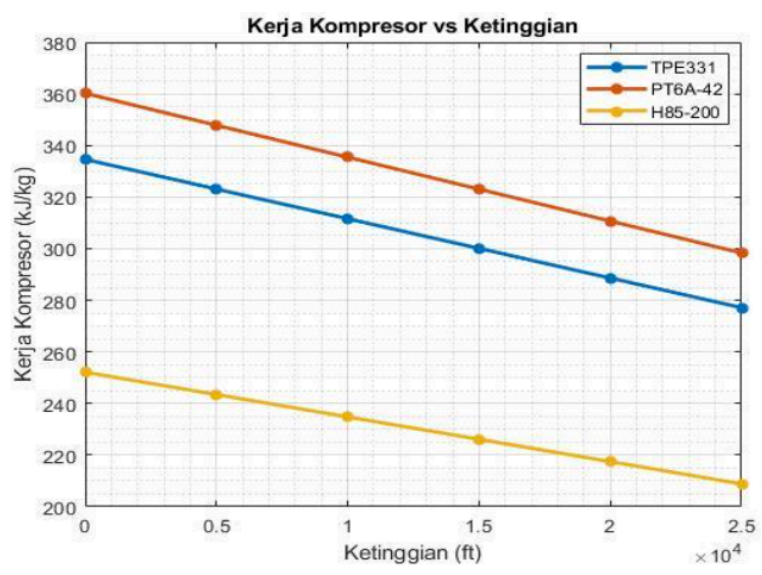

Gambar 4.4 Grafik Perbandingan Kerja Kompresor antara Engine TPE331-10, PT6A-42 dan H85-200 terhadap Variasi Ketinggian

\subsubsection{Fuel to Air Ratio}

Fuel to air ratio merupakan perbandingan campuran bahan bakar dan udara yang digunakan untuk proses pembakaran. Pada gambar 4.5 ditunjukkan perbandingan grafik mesin TPE-331-10, PT6A-42 dan HE85-200 terhadap variasi ketinggian. Pada grafik tersebut ditunjukkan bahwa seiring kenaikan ketinggian maka rasio pencampuran bahan bakar dan udara mengalami peningkatan. Hal ini diakibatkan oleh suhu yang semakin rendah pada stage kompresor seiring dengan kenaikan ketinggian. Pada grafik tersebut ditunjukkan bahwa nilai fuel to 
air ratio terendah ada pada mesin PT6A42 karena mesin ini memiliki nilai compressor pressure ratio yang tinggi dibandingkan dengan TPE-331 dan H85200. Nilai persentase jumlah campuran bahan bakar dan udara untuk mesin PT6A-42 rata-rata $3.04 \%$ lebih rendah dibandingkan TPE-331 dan $11.60 \%$ dibandingkan H85-200 terhadap variasi ketinggian.

Tabel 4.2 Perbandingan Fuel to Air Ratio antara Engine TPE331-10, PT6A42 dan H85- 200 terhadap Variasi Ketinggian

\begin{tabular}{|c|c|c|c|}
\hline \multirow{2}{*}{$\begin{array}{c}\text { Ketinggian } \\
\text { (ft) }\end{array}$} & \multicolumn{3}{|c|}{ Fuel to Air Ratio } \\
\cline { 2 - 4 } & TPE331-10 & PT6A-42 & H85-200 \\
\hline $\mathbf{0}$ & 0.0177 & 0.0170 & 0.0197 \\
\hline $\mathbf{5 0 0 0}$ & 0.0182 & 0.0176 & 0.0201 \\
\hline $\mathbf{1 0 0 0 0}$ & 0.0187 & 0.0182 & 0.0206 \\
\hline $\mathbf{1 5 0 0 0}$ & 0.0193 & 0.0187 & 0.0211 \\
\hline $\mathbf{2 0 0 0 0}$ & 0.0198 & 0.0193 & 0.0215 \\
\hline $\mathbf{2 5 0 0 0}$ & 0.0203 & 0.0198 & 0.0220 \\
\hline
\end{tabular}

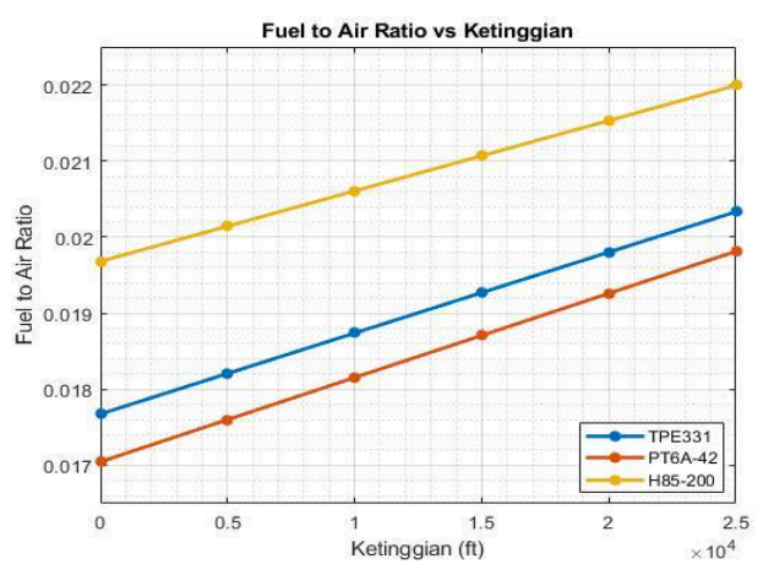

Gambar 4.5 Grafik Perbandingan Fuel to Air Ratio antara Engine TPE331-10, PT6A-42 dan H85-200 terhadap Variasi Ketinggian

\subsubsection{Fuel Mass Flow Rate}

Fuel mass flow rate merupakan nilai aliran massa bahan bakar ke ruang bakar. Pada gambar 4.6 ditunjukkan grafik perbandingan antara fuel mass flow rate terhadap variasi ketinggian.
Dari grafik tersebut dapat dilihat bahwa seiring dengan kenaikan ketinggian maka fuel mass flow rate semakin kecil karena semakin berkurangnya kerapatan udara sehingga jumlah laju aliran massa udara yang masuk kedalam mesin semakin berkurang akibatnya laju aliran fuel semakin berkurang juga sesuai dengan rasio pencampuran bahan bakar dan udara. Selain itu, laju aliran bahan bakar yang masuk ke mesin PT6A-42 lebih sedikit per detiknya dengan nilai rata-rata $3.04 \%$ dibandingkan dengan mesin TPE- 331 dan 18.8\% dibandingkan dengan mesin H85-200. Hal ini disebabkan oleh nilai compressor pressure ratio mesin PT6A-42 yang lebih tinggi dibandingkan dengan TPE-331 dan $\mathrm{H} 85-200$..

Tabel 4.3 Perbandingan Fuel Flow Rate antara Engine TPE331-10, PT6A-42 dan H85-200 terhadap Variasi Ketinggian

\begin{tabular}{|c|c|c|c|}
\hline \multirow{2}{*}{$\begin{array}{c}\text { Ketinggian } \\
\text { (ft) }\end{array}$} & \multicolumn{3}{|c|}{ Fuel Flow Rate (kg/s) } \\
\cline { 2 - 4 } & TPE331-10 & PT6A-42 & H85-200 \\
\hline $\mathbf{0}$ & 0.062 & 0.060 & 0.075 \\
\hline $\mathbf{5 0 0 0}$ & 0.055 & 0.053 & 0.066 \\
\hline $\mathbf{1 0 0 0 0}$ & 0.049 & 0.047 & 0.058 \\
\hline $\mathbf{1 5 0 0 0}$ & 0.042 & 0.041 & 0.050 \\
\hline $\mathbf{2 0 0 0 0}$ & 0.037 & 0.036 & 0.043 \\
\hline $\mathbf{2 5 0 0 0}$ & 0.032 & 0.031 & 0.037 \\
\hline
\end{tabular}




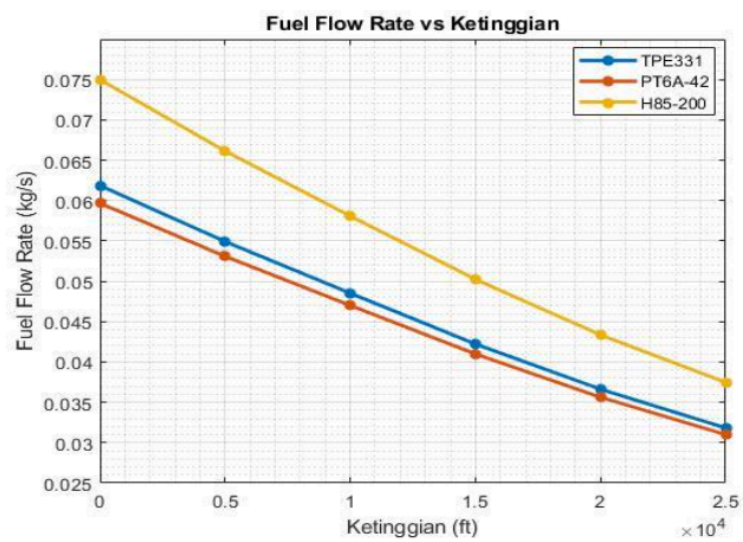

Gambar 4.6 Grafik Perbandingan Fuel Flow Rate antara Engine TPE331-10, PT6A-42 dan H85-200 terhadap Variasi Ketinggian

\subsubsection{Kerja Turbin}

Kerja turbin merupakan kerja total dari seluruh stage turbin yang ada pada mesin. Pada gambar 4.7 ditunjukkan bahwa grafik kerja turbin relatif stabil seiring dengan kenaikan ketinggian. Hal ini disebabkan oleh nilai suhu yang sama setelah pembakaran pada combustion chamber. Pada grafik tersebut ditunjukkan bahwa kerja turbin dari mesin PT6A-42 lebih tinggi $6.82 \%$ dibandingkan dengan mesin TPE331-10 dan $18.4 \%$ dibandingkan dengan mesin H85-200. Hal ini disebabkan oleh nilai compressor pressure ratio mesin PT6A42 yang lebih tinggi dibandingkan dengan TPE-331 dan H85-200.

Tabel 4.4 Perbandingan Kerja Turbin antara Engine TPE331-10, PT6A-42 dan H85-200 terhadap Variasi Ketinggian

\begin{tabular}{|c|c|c|c|}
\hline \multirow{2}{*}{$\begin{array}{c}\text { Ketinggian } \\
\text { (ft) }\end{array}$} & \multicolumn{3}{|c|}{ Kerja Turbin (kJ/kg) } \\
\cline { 2 - 4 } & TPE331-10 & PT6A-42 & H85-200 \\
\hline $\mathbf{0}$ & 549.05 & 589.27 & 480.84 \\
\hline $\mathbf{5 0 0 0}$ & 549.05 & 589.13 & 480.59 \\
\hline $\mathbf{1 0 0 0 0}$ & 549.05 & 588.95 & 480.32 \\
\hline $\mathbf{1 5 0 0 0}$ & 549.05 & 588.73 & 480.03 \\
\hline $\mathbf{2 0 0 0 0}$ & 549.05 & 588.46 & 479.72 \\
\hline $\mathbf{2 5 0 0 0}$ & 549.05 & 588.16 & 479.39 \\
\hline
\end{tabular}

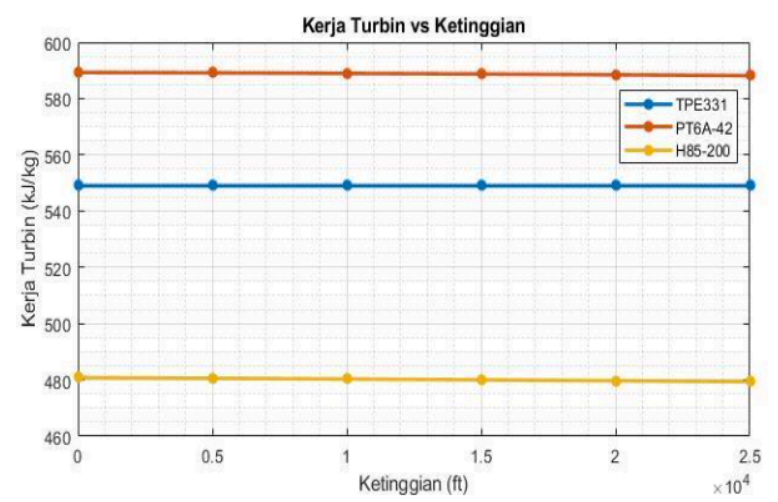

Gambar 4.7 Perbandingan Kerja Turbin antara Engine TPE331-10, PT6A42 dan H85-200 terhadap Variasi Ketinggian

\subsubsection{Kerja Poros}

Kerja poros untuk poros tunggal merupakan selisih dari kerja turbin dengan kerja kompresor sedangkan untuk poros ganda merupakan kerja free turbine dikalikan dengan efisiensi mekanik. Pada Gambar 4.8 ditunjukkan bahwa kerja poros mengalami kenaikan seiring dengan kenaikan ketinggian. Hal ini disebabkan oleh penurunan kerja kompresor untuk poros tunggal dan penurunan kerja free turbine untuk poros ganda seiring dengan kenaikan ketinggian. Pada grafik tersebut ditunjukkan bahwa kerja poros paling tinggi pada sea level yaitu ada pada mesin H85- 200 tetapi setelah ketinggian $5000 \mathrm{ft}$ hingga $25000 \mathrm{ft}$, kerja poros tertinggi berada pada mesin PT6A-42. 
Jurnal Teknologi Kedirgantaraan, Vol, VI No. 2, Agustus 2021, P-ISSN 2528-2778, E-ISSN 2684-9704 https://doi.org/10.35894/jtk.v6i2

Tabel 4.5 Perbandingan Kerja Poros antara Engine TPE331-10, PT6A-42 dan H85-200 terhadap Variasi Ketinggian

\begin{tabular}{|c|c|c|c|}
\hline \multirow{2}{*}{$\begin{array}{c}\text { Ketinggian } \\
\text { (ft) }\end{array}$} & \multicolumn{3}{|c|}{ Kerja Poros (kJ/kg) } \\
\cline { 2 - 4 } & TPE331-10 & PT6A-42 & H85-200 \\
\hline $\mathbf{0}$ & 206.15 & 213.52 & 218.17 \\
\hline $\mathbf{5 0 0 0}$ & 218.18 & 226.36 & 227.04 \\
\hline 10000 & 230.20 & 239.16 & 235.90 \\
\hline 15000 & 242.21 & 251.93 & 244.74 \\
\hline 20000 & 254.23 & 264.67 & 253.57 \\
\hline 25000 & 266.23 & 277.37 & 262.37 \\
\hline
\end{tabular}

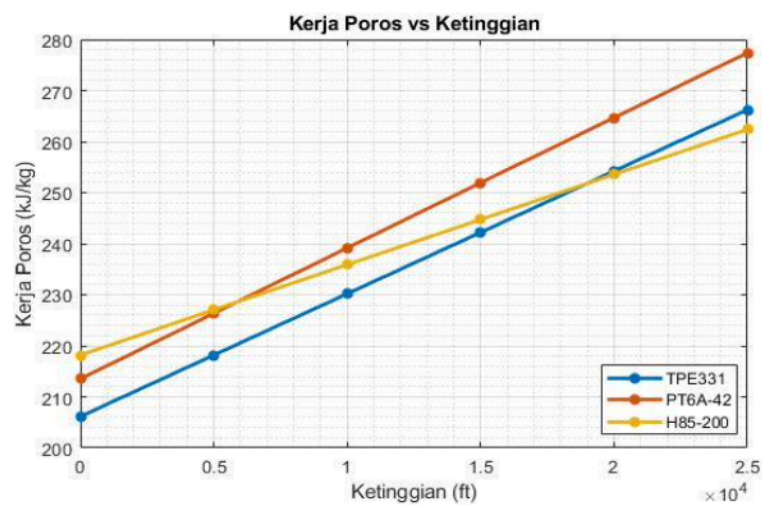

Gambar 4.8 Perbandingan Kerja Poros antara Engine TPE331-10, PT6A-42 dan H85-200 terhadap Variasi Ketinggian

\subsubsection{Daya Poros}

Daya poros adalah kerja poros dikalikan dengan laju aliran massa udara. Pada gambar 4.9 grafik daya poros menurun seiring dengan kenaikan ketinggian. Hal ini disebabkan oleh laju aliran massa udara ambient yang mengalami penurunan akibat dari kerapatan udara yang semakin kecil seiring dengan kenaikan ketinggian. Pada grafik tersebut ditunjukkan bahwa daya poros terbesar ada pada mesin H85-200 karena memiliki laju aliran massa udara yang lebih besar dibandingkan dengan mesin TPE- 331 dan PT6A-42. Daya poros mesin H85200 memiliki nilai rata-rata lebih besar $9.84 \%$ dibandingkan dengan mesin
TPE331-10 dan $6.3 \%$ dengan mesin PT6A-42.

Tabel 4.6 Perbandingan Daya Poros antara Engine TPE331-10, PT6A-42 dan H85-200 terhadap Variasi Ketinggian

\begin{tabular}{|c|c|c|c|}
\hline \multirow{2}{*}{$\begin{array}{c}\text { Ketinggian } \\
\text { (ft) }\end{array}$} & \multicolumn{3}{|c|}{ Daya Poros (kW) } \\
\cline { 2 - 4 } & TPE331-10 & PT6A-42 & H85-200 \\
\hline $\mathbf{0}$ & 721.53 & 747.31 & 831.23 \\
\hline $\mathbf{5 0 0 0}$ & 658.09 & 682.76 & 745.48 \\
\hline $\mathbf{1 0 0 0 0}$ & 596.08 & 619.29 & 664.94 \\
\hline $\mathbf{1 5 0 0 0}$ & 530.70 & 551.99 & 583.73 \\
\hline $\mathbf{2 0 0 0 0}$ & 470.22 & 489.54 & 510.53 \\
\hline $\mathbf{2 5 0 0 0}$ & 416.66 & 434.10 & 446.99 \\
\hline
\end{tabular}

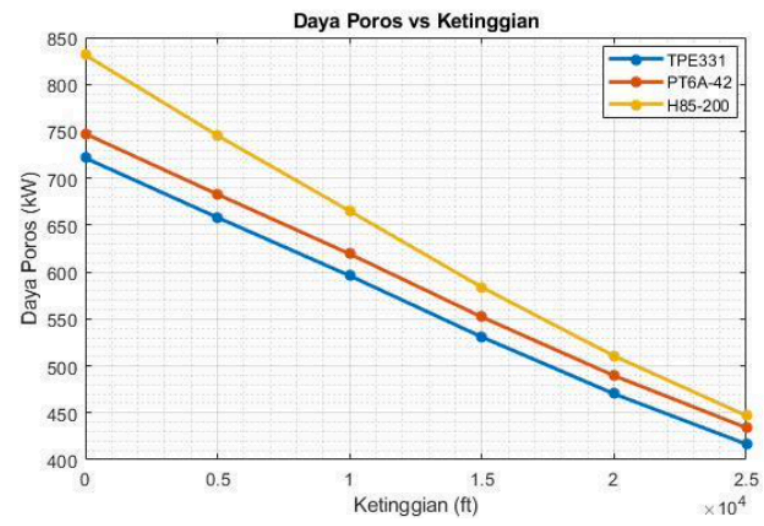

Gambar 4.9 Grafik Perbandingan Daya Poros antara Engine TPE331-10, PT6A42 dan H85- 200 terhadap Variasi Ketinggian

\subsubsection{Propeller Thurst}

Propeller thrust adalah gaya dorong yang dihasilkan oleh propeller yang terhubung ke gearbox. Pada Gambar 4.10 dapat dilihat bahwa seiring kenaikan ketinggian propeller thrust semakin berkurang. Hal ini diakibatkan oleh daya yang ditransmisikan ke propeller mengalami penurunan seiring dengan kenaikan ketinggian. Pada Grafik tersbut juga ditunjukkan bahwa pada ketinggian sea level mesin H85-200 memiliki propeller thrust lebih besar $7.41 \%$ dibandingkan mesin TPE331-10 dan 
4.1\% dibandingkan dengan mesin PT6A42. Akan tetapi, pada ketinggian $15000 \mathrm{ft}$ hingga $25000 \mathrm{ft}$, mesin PT6A-42 memiliki thrust lebih besar dibandingkan mesin TPE331-10 dan H85-200.

Tabel 4.7 Perbandingan Propeller Thrust antara Engine TPE331-10, PT6A-42 dan H85- 200 terhadap Variasi Ketinggian

\begin{tabular}{|c|c|c|c|}
\hline \multirow{2}{*}{$\begin{array}{c}\text { Ketinggian } \\
\text { (ft) }\end{array}$} & \multicolumn{3}{|c|}{ Propeller Thrust (kN) } \\
\cline { 2 - 4 } & TPE331-10 & PT6A-42 & H85-200 \\
\hline $\mathbf{0}$ & 5.95 & 6.16 & 6.43 \\
\hline $\mathbf{5 0 0 0}$ & 5.43 & 5.63 & 5.76 \\
\hline $\mathbf{1 0 0 0 0}$ & 4.91 & 5.11 & 5.14 \\
\hline $\mathbf{1 5 0 0 0}$ & 4.38 & 4.55 & 4.51 \\
\hline $\mathbf{2 0 0 0 0}$ & 3.88 & 4.04 & 3.95 \\
\hline $\mathbf{2 5 0 0 0}$ & 3.44 & 3.58 & 3.46 \\
\hline
\end{tabular}

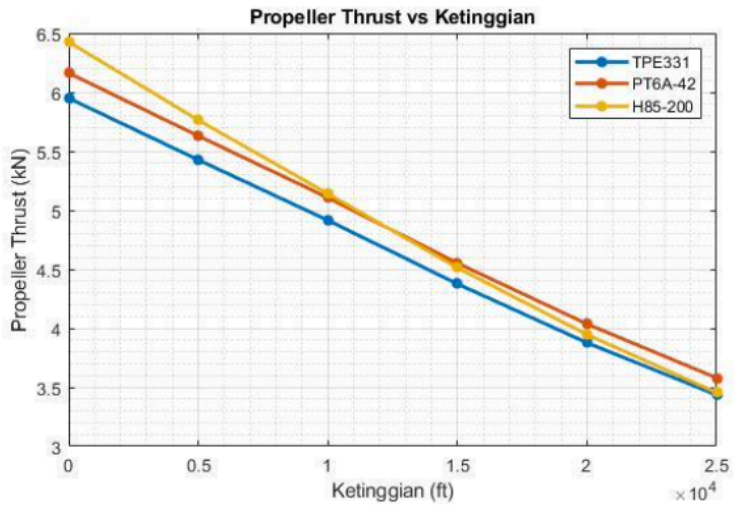

Gambar 4.10 Grafik Perbandingan Propeller Thrust antara Engine TPE33110, PT6A-42 dan H85-200 terhadap Variasi Ketinggian

\subsubsection{Jet Thurst}

Jet thrust adalah gaya dorong yang dihasilkan pada saat udara keluar melalui nozzle/exhaust. Pada Gambar 4.11 dapat dilihat bahwa seiring dengan kenaikan ketinggian maka jet thrust semakin kecil. Hal ini disebabkan oleh kerapatan udara yang semakin kecil seiring dengan kenaikan ketinggian sehingga mengakibatkan laju aliran massa perdetiknya semakin berkurang. Pada grafik ditunjukkan bahwa nilai jet thrust tertinggi ada pada mesin $\mathrm{H} 85-200$. Hal ini disebabkan oleh laju aliran massa udara pada mesin H85-200 lebih tinggi dibandingkan dengan mesin TPE331-10 dan PT6A-42. Nilainya lebih tinggi ratarata sebesar $14.51 \%$ dibandingkan dengan mesin TPE-331 dan 14.72\% dibandingkan dengan mesin PT6A-42.

Tabel 4.8 Perbandingan Jet Thrust antara Engine TPE331-10, PT6A-42 dan H85-200 terhadap Variasi Ketinggian

\begin{tabular}{|c|c|c|c|}
\hline \multirow{2}{*}{$\begin{array}{c}\text { Ketinggian } \\
\text { (ft) }\end{array}$} & \multicolumn{3}{|c|}{ Jet Thrust (kN) } \\
\cline { 2 - 4 } & TPE331-10 & PT6A-42 & H85-200 \\
\hline $\mathbf{0}$ & 0.11 & 0.11 & 0.13 \\
\hline $\mathbf{5 0 0 0}$ & 0.10 & 0.10 & 0.11 \\
\hline $\mathbf{1 0 0 0 0}$ & 0.08 & 0.08 & 0.10 \\
\hline $\mathbf{1 5 0 0 0}$ & 0.07 & 0.07 & 0.08 \\
\hline $\mathbf{2 0 0 0 0}$ & 0.06 & 0.06 & 0.07 \\
\hline $\mathbf{2 5 0 0 0}$ & 0.05 & 0.05 & 0.06 \\
\hline
\end{tabular}

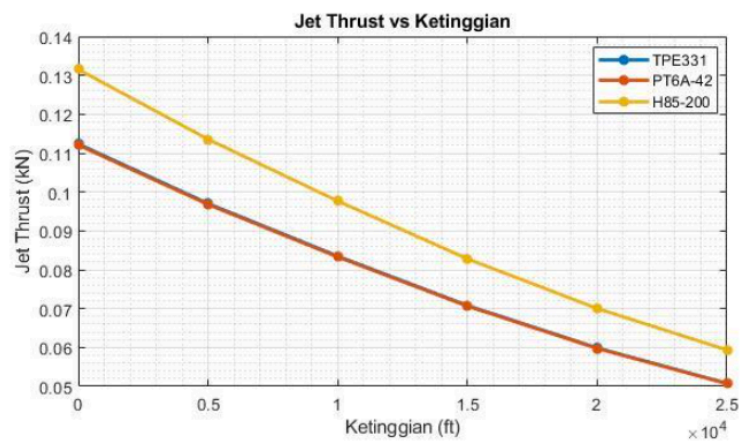

Gambar 4.11 Grafik Perbandingan Jet Thrust antara Engine TPE331-10, PT6A-42 dan H85- 200 terhadap Variasi Ketinggian

\subsubsection{Total Thrust}

Total thrust merupakan penjumlahan thrust yang dihasilkan oleh propeller ditambah dengan thrust yang dihasilkan dari jet. Pada gambar 4.12 dapat dilihat bahwa nilai total thrust semakin kecil seiring dengan kenaikan. Pada Grafik tersbut juga ditunjukkan bahwa pada 
ketinggian sea level mesin $\mathrm{H} 85-200$ memiliki total thrust lebih besar $7.56 \%$ dibandingkan mesin TPE331-10 dan $4.32 \%$ dibandingkan dengan mesin PT6A-42. Akan tetapi, pada ketinggian $15000 \mathrm{ft}$ hingga $25000 \mathrm{ft}$, mesin PT6A-42 memiliki thrust lebih besar dibandingkan mesin TPE331-10 dan H85-200.

Tabel 4.9 Perbandingan Total Thrust antara Engine TPE331-10, PT6A-42 dan H85-200 terhadap Variasi Ketinggian

\begin{tabular}{|c|c|c|c|}
\hline \multirow{2}{*}{$\begin{array}{c}\text { Ketinggian } \\
\text { (ft) }\end{array}$} & \multicolumn{3}{|c|}{ Total Thrust (kN) } \\
\cline { 2 - 4 } & $\begin{array}{c}\text { TPE331- } \\
\mathbf{1 0}\end{array}$ & PT6A-42 & H85-200 \\
\hline $\mathbf{0}$ & 6.06 & 6.27 & 6.56 \\
\hline $\mathbf{5 0 0 0}$ & 5.52 & 5.73 & 5.88 \\
\hline $\mathbf{1 0 0 0 0}$ & 5.00 & 5.19 & 5.24 \\
\hline $\mathbf{1 5 0 0 0}$ & 4.45 & 4.62 & 4.60 \\
\hline $\mathbf{2 0 0 0 0}$ & 3.94 & 4.10 & 4.02 \\
\hline $\mathbf{2 5 0 0 0}$ & 3.49 & 3.63 & 3.51 \\
\hline
\end{tabular}

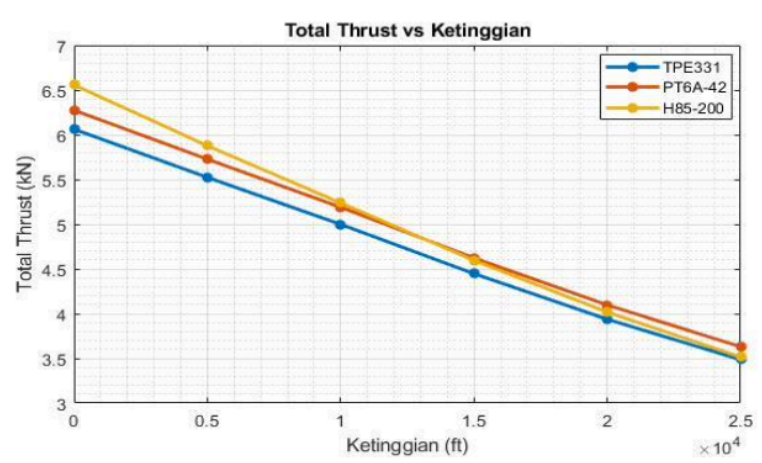

Gambar 4.12 Grafik Perbandingan Total Thrust antara Engine TPE331-10, PT6A-42 dan H85- 200 terhadap Variasi Ketinggian

\subsection{Equivalent Engine Power}

Equivalent Engine Power merupakan nilai penjumlahan dari propeller power ditambahkan dengan jet power. Pada gambar 4.13 ditunjukkan grafik equivalent power terhadap variasi ketinggian, dapat dilihat bahwa seiring dengan kenaikan ketinggian nilai equivalent power semakin menurun akibat nilai thrust yang juga semakin menurun. Pada grafik ini juga dapat dilihat bahwa nilai equivalent power tertinggi ada pada mesin $\mathrm{H} 85-200$ yaitu rata-rata $10.02 \%$ lebih tinggi dibandingkan dengan mesin TPE-331 dan $6.55 \%$ lebih tinggi dibandingkan dengan mesin PT6A- 42.

Tabel 4.10 Perbandingan Equivalent Power antara Engine TPE331-10, PT6A-42 dan H85- 200 terhadap Variasi Ketinggian

\begin{tabular}{|c|c|c|c|}
\hline \multirow{2}{*}{$\begin{array}{c}\text { Ketinggian } \\
\text { (ft) }\end{array}$} & \multicolumn{3}{|c|}{ Equivalent Power (kW) } \\
\cline { 2 - 4 } & TPE331-10 & PT6A-42 & H85-200 \\
\hline $\mathbf{0}$ & 618.63 & 640.30 & 713.80 \\
\hline $\mathbf{5 0 0 0}$ & 563.68 & 584.43 & 639.69 \\
\hline $\mathbf{1 0 0 0 0}$ & 510.12 & 529.63 & 570.18 \\
\hline $\mathbf{1 5 0 0 0}$ & 453.81 & 471.71 & 500.22 \\
\hline $\mathbf{2 0 0 0 0}$ & 401.80 & 418.04 & 437.24 \\
\hline $\mathbf{2 5 0 0 0}$ & 355.80 & 370.47 & 382.61 \\
\hline
\end{tabular}

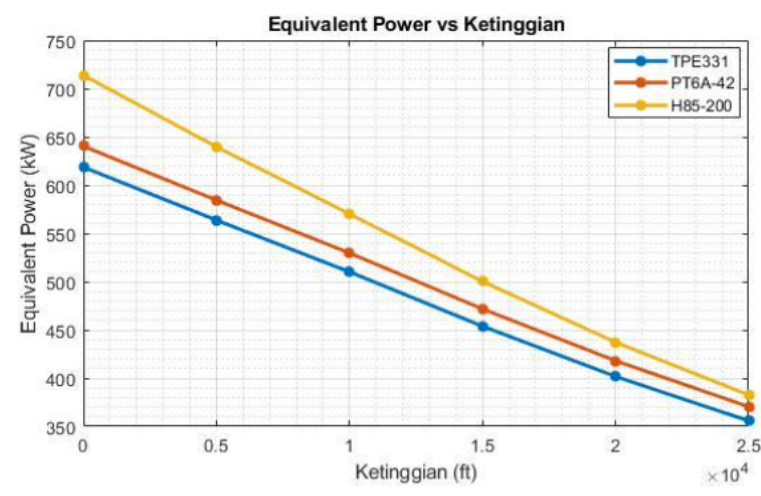

Gambar 4.13 Grafik Perbandingan Equivalent Power antara Engine TPE331-10, PT6A-42 dan H85-200 terhadap Variasi Ketinggian

\subsection{Equivalent Specific Fuel Consumption (ESFC)}

ESFC atau Equivalent Specific Fuel Consumption menyatakan jumlah massa fuel yang dibutuhkan persatuan daya dikalikan dengan waktu. Pada Gambar 4.14 diapat dilihat bahwa nilai ESFC semakin kecil seiring dengan kenaikan ketinggian. Pada grafik tersebut 
ditunjukkan bahwa nilai ESFC terkecil ada pada mesin PT6A-42, yaitu rata-rata $6.63 \%$ lebih kecil dibandingkan dengan mesin TPE331-10 dan $13.06 \%$ dibandingkan dengan mesin $\mathrm{H} 85-200$. Hal ini disebabkanoleh nilai compressor pressure ratio mesin PT6A-42 yang lebih tinggi dibandingkan dengan TPE-331 dan $\mathrm{H} 85-200$.

Tabel 4.11 Perbandingan ESFC antara Engine TPE331-10, PT6A-42 dan H85200 terhadap Variasi Ketinggian

\begin{tabular}{|c|c|c|c|}
\hline \multirow{2}{*}{$\begin{array}{c}\text { Ketinggian } \\
\text { (ft) }\end{array}$} & \multicolumn{3}{|c|}{ ESFC (kg fuel/kW.h) } \\
\cline { 2 - 4 } & TPE331-10 & PT6A-42 & H85-200 \\
\hline $\mathbf{0}$ & 0.360 & 0.335 & 0.378 \\
\hline $\mathbf{5 0 0 0}$ & 0.351 & 0.327 & 0.372 \\
\hline $\mathbf{1 0 0 0 0}$ & 0.342 & 0.320 & 0.367 \\
\hline $\mathbf{1 5 0 0 0}$ & 0.335 & 0.313 & 0.362 \\
\hline $\mathbf{2 0 0 0 0}$ & 0.328 & 0.307 & 0.357 \\
\hline $\mathbf{2 5 0 0 0}$ & 0.322 & 0.301 & 0.353 \\
\hline
\end{tabular}

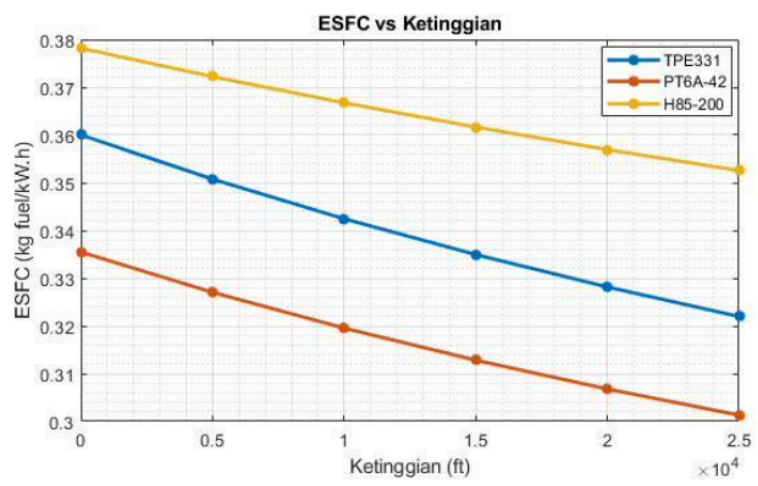

Gambar 4.14 Grafik Perbandingan ESFC antara Engine TPE331-10, PT6A42 dan H85- 200 terhadap Variasi Ketinggian

\section{Kesimpulan}

Dari pembuatan dan penggunaan hasil perhitungan analisis termodinamika pada mesin turboprop menggunakan software dan perbandingan menggunakan tabel serta grafik, maka dapat diambil beberapa kesimpulan sebagai berikut:
1. Pembuatan software menggunakan aplikasi Matlab dapat dilakukan melalui fungsi "Guide" dengan mengetik kata "guide" pada command window Matlab.

2. Pada mesin turboprop TPE331-10, PT6A-42, dan H85-200 nilai fuel to air ratio dan kerja poros mengalami kenaikan seiring dengan kenaikan ketinggian sedangkan kerja kompresor, fuel flow rate, daya poros, propeller thrust, jet thrust, total thrust, equivalent engine power dan ESFC mengalami penurunan seiring dengan kenaikan ketinggian. Selanjutnya, nilai kerja turbin relatif stabil seiring dengan kenaikan ketinggian.

3. Nilai kerja kompresor dan kerja turbin pada mesin PT6A-42 lebih besar dibandingkan dengan mesin TPE331- 10, dan H85-200. Akan tetapi, nilai fuel to air ratio, fuel flow rate, daya poros, jet thrust, equivalent engine power dan ESFC pada mesin H85-200 lebih besar dibandingkan mesin TPE331-10 dan PT6A. Selanjutnya, pada ketinggian sea level, nilai kerja poros, propeller thrust, dan total thrust pada mesin H85-200 lebih besar dibandingkan dengan mesin TPE331-10 dan PT6A-42 tetapi pada ketinggian $25.000 \mathrm{ft}$, mesin PT6A-42 memiliki nilai yang lebih besar dibandingkan mesin TPE331-10, dan H85-200.

\section{DAFTAR PUSTAKA}

[1] EL-Sayed, Ahmed F., 2017, Aircraft Propulsion and Gas Turbine Engine; CRC Press taylor and francis group., ISBN-13: 978-14665-9516-3 (hardback) ISBN 9781466595187 (ebook); 2017. 
[2] Rabeta, B., 2020, Perbandingan Analisis Termodinamika Mesin TPE331-10 Dan PT6A-42 Terhadap Variasi Ketinggian Terbang, Jurnal Teknologi Kedirgantaraan, Vol, V No. 2, Agustus 2020, P-ISSN 2528-2778, E-ISSN 2684-9704, Universitas Dirgantara Marsekal Suryadarma. shola,

[3] Rasheed Michael, 2020, Thermodynamic Analysis of a Turboprop Engine With Regeneration and Intercooling, Politecnico Milano 1863.

[4] Astari, N., 2018, Analisis Kinerja Mesin Eksperimental Propfan Pratt \& Whitney / Allison 578-Dx Berbasis Matlab R2017a, Skripsi Teknologi Kedirgantaraan, Universitas Dirgantara Marsekal Suryadarma

[5] Daly, Mark, 2015, Jane's AeroEngines 2016-2017, London Ihs jane's.

[6] LET Aircraft Industries, L 410, http://www.let.cz/en/1410ng, diakses tanggal 11 November 2020.

[7] Air-Tec Global, Air-Tec's Turboprop Engines, GE H85 Turboprop Engine, https://www.air-tecm.com/air-tecsturbo-prop-engines/, diakses tanggal 25 Januari 2021.

[8] Eeuropean Union Aviation Safety Agency, 2020, Type-Certificate Data Sheet No. EASA.A.206 for L410.

[9] Eeuropean Union Aviation Safety Agency, 2017, Type-Certificate Data Sheet No. E.070 for M601/H85 Series Engine. 